\title{
THE EFFECT OF CARDAMOM AND CORIANDER OILS ON THE MICROBIOLOGICAL LOAD AND QUALITY OF MEAT SAUSAGE
}

Ebeid, H. M. ${ }^{(1)}$; El-Tayeb, T. S. ${ }^{(1)}$; Arafat, Sh. M. ${ }^{(2)}$ and Gad, G. H. ${ }^{(3)}$ 1) Faculty of Agriculture,Ain Shams University 2) Food Technology Research Institute, Agricultural Research Centre 3) Kato Flavors and Fragrance company

\begin{abstract}
The object of the present study is evaluation of possibility of using cardamom and coriander oils mixture $(1: 4 \mathrm{w} / \mathrm{w})$ as natural antimicrobial in meat sausage industry to increase the shelf-life of sausage. The physical and chemical properties of the sausage was improved by addition of cardamom and coriander oils mixture at the concentrations of 600,900 and $1200 \mathrm{ppm}$ to sausage before storage at $-18^{\circ} \mathrm{C}$ for 3 months. The moisture, protein content and carbohydrates were decreased about 1.06, 1.02 and 0.90 fold as compared to zero time, respectively. Whereas, ash, $\mathrm{pH}$ value and fat content increased up to $6.19,18.44$, and $6.31 \%$, respectively, as compared to zero time. Improvement has been observed after addition of cardamom and coriander oils mixture and, it works to increase the storage period of the sausage and maintain the stability of the desired qualities for consumers. Regarding to microbial load, samples treated with 900 and 1200 ppm of oils mixture revealed significant reduction after 90 day of storage as compared with the control samples. Sample (1200 ppm) had the highest score for overall acceptable among all investigated samples. Addition of cardamom and coriander oils shows growth inhibition to some types of bacteria and fungi.

Key words: Sausage, Chemical composition, Microbiological quality, Sensory characteristics
\end{abstract}


J. Environ. Sci.

Institute of Environmental Studies and Research - Ain Shams University

\section{INTRODUCTION}

Food safety is a fundamental concern for both consumers and food producers alike. Despite the high degree ofawareness of food preservation methods there is increasing occurrence of disease outbreaks caused bypathogenic and spoilage microorganisms in foods (Meng\& Doyle, 1998). Currently some ready mealmanufacturers add synthetic antimicrobial agents such nitrates, nitrites, benzoates to inhibit the growth of foodspoilage and food pathogenic microorganisms (Gould, 1996). However, the uncontrolled use of chemicalpreservatives over the years has led to emergence of microbial resistance to classic antimicrobial agents whichhas become a major health concern (Kiesslinget al., 2002). Consumer awareness and concern that syntheticchemical additives may have some toxic or even carcinogenic effects, has increased the demand for high-quality,minimally processed foods with extended shelf-life, preferably free from or with a reduced level of addedchemical antimicrobial agents (Zink, 1997). Recently there has also been an observed trend towards reducing saltlevels in ready meals as a result of the proven association between excessive sodium intake, the development ofhypertension and increased risk of cardiovascular disease (Desmond, 2006). Therefore, there is growing interestin using natural antimicrobial compounds, including extracts of herbs and spices, as salt replacers or alternativesto synthetic compounds for food preservation (Smid\&Gorris, 1999). Recently it has become very interesting and highly recommended to use naturalantioxidants as food additives by the food industry (Solomakos et al., 2008; Karre et al., 2013). 
Essential oils from aromatic and medicinal plants has been known to possess potential as natural agents for food preservation, including antibacterial, antifungal and antioxidant; in fact, many essential oils have been qualified as natural antioxidants and offered as potential substitutes of synthetic antioxidants in specific sections of food preservation where their use is not in contrast with their aroma (Ruberto and Baratta 2000; Polite0o et al., 2007). Antioxidants are used in the food industry to increase the shelf life of the foods. Antioxidants can also prevent the reaction of free radicals with biomolecules in the human body and reduce cell injury and death, chronic and cardiovascular diseases and etc. (Ayoughi et al., 2011).Natural aromatic plants and spices have been widely used in many food products such as meat and meat products, dairy and bakery products for preserving and for their medicinal value (Reddy et al., 2005; Shahsavari et al., 2008). Most antioxidant activity investigations have been managed on refined oils (Lean and Mohamed, 1999).Cardamom oil is used in food, perfumery, and liquor a pharmaceutical industries as a flavour and a carminative. In medicine, it is used as a powerful aromatic, antiseptic, stimulant, carminative, stomachic, expectorant, anti-spasmodic and diuretic (Baytop (1984) Korikontimath, et al., (1999)).Cardamom has antioxidant properties and can increase levels of glutathione and antioxidant enzymes in the body.

Coriander seeds are also used as a flavoring agent in different foods namely pastries, cookies, buns, cakes and breads (Akgul, 1993; Coskuner and Karababa, 2007; Bhuiyanet al., 2009). In addition to the traditional food uses, these have been widely used in the folk medicine system as carminative, spasmolytic, digestive, and galactagogue (Ghani, 2003; Bhuiyanet al., 2009). 
This plant is of economic importance since it has been used as a flavoring agent in food products, perfumes, cosmetics and drugs. This culinary and medicinal plant widely distributed and mainly cultivated for the seeds which contain an essential oil (ranges between $0.3 \%$ and 1.1\%) (Neffatiet al., 2011).The object of the present study is evaluation of possibility of using cardamom and coriander oils mixture $(1: 4 \mathrm{w} / \mathrm{w})$ as natural antimicrobial in meat sausage industry

\section{MATERIALS AND METHODS}

Source of samples: Cardamom and coriander oils were purchased from Kato Aromatic Company (Cairo, Egypt).Meats was obtained from local commercial markets.

Preparation of meat sausage: Frozen boneless meats was thawed at $10^{\circ} \mathrm{C}$ just before sausage manufacture. It was ground through a $0.4-\mathrm{cm}$ grinder plate (Super grinder-MK-G3; Matsushita Electric Industrial, Japan). These corresponding levels of the two oil mixed (cardamom and coriander 1:4 w/w) forms are weight equivalent. The ingredients of sausage sample were as showed in Table (1).

This formula was mixed in an emulsifier (Kenmix Electronic, model FP800, Kenwood Ltd., Britain) for $3 \mathrm{~min}$ and the resulting mixture was stuffed tightly into hydrocellulose casings $1.5 \mathrm{~cm}$ in diameter (Viskase Corporation, Chicago, USA), which were subsequently divided into foodcasing lengths of about $12 \mathrm{~cm}$ per unit. The sausage units were vacuum packaged in polyethylene bags, labeled and stored at $-18^{\circ} \mathrm{C}$ for 3 months. 
Table (1): Ingredients of Sausage

\begin{tabular}{|c|c|}
\hline Ingredients & Weight (g) \\
\hline Sausage meat & 850 \\
\hline Fat & 150 \\
\hline Starch & 50 \\
\hline Sodium chloride & 20 \\
\hline Sodium polyphosphate & 15.5 \\
\hline Glucose & 10 \\
\hline Monosodium glutamate & 5 \\
\hline Black pepper & 3 \\
\hline Ascorbic acid & 0.40 \\
\hline sodium nitrate & 0.1 \\
\hline
\end{tabular}

To the above formula mixture of oils cardamom and coriander (1:4 w/w),Spices mixture oils (600,900 and 1200 ppm) were added

Culture preparation: A loopful of $24 \mathrm{~h}$ surface growth on a NA (Nutrient Agar) slope of each bacterial strain (NA) was transferred individually to $5 \mathrm{ml}$ of Brain Heart Infusion (BHI) broth (pH 7.6, Difco). After incubation at $37^{\circ} \mathrm{C}$ for $24 \mathrm{~h}$, bacterial cells were collected by centrifugation at $3000 \mathrm{rpm}$ for 15 min, washed twice and suspended in $0.1 \%$ peptone water. Turbidity was adjusted to match that of a $5 \mathrm{McF}$ arland standard $\left(10^{7} \mathrm{CFU} / \mathrm{ml}\right)$. Then, a 1:10 dilution of the cell suspension was performed to give an inoculum concentration of $10^{7} \mathrm{CFU} / \mathrm{ml}$.

Aerobic plate count: Sausage sample (10 g) was homogenized with $90 \mathrm{ml}$ of sterile peptone water $(1 \mathrm{~g} / \mathrm{l})$ in a laboratory homogenizer (AM-5 Ace homogenizer, Nihonseiki, Japan) and serial dilutions were prepared, then 0.1 $\mathrm{ml}$ of each dilution was spread with a bent sterile glass rod on duplicate plates 
of pre-poured and dried standard plate count agar (Nissui Pharmaceutical, Japan). After $48 \mathrm{~h}$ incubation at $25^{\circ} \mathrm{C}$, colonies were counted and results were expressed as $\log \mathrm{CFU} / \mathrm{g}$ of sausage sample.

Chemical analysis: Moisture content, crude protein (total $\mathrm{N}$ x 6.25), fat and ash contents were determined according to A.O.A.C. (2000). Total carbohydrates content was calculated by differences. For determination of the $\mathrm{pH}, 10 \mathrm{~g}$ of sample were homogenized with $50 \mathrm{ml}$ distilled water and $\mathrm{pH}$ value was measured by a digital $\mathrm{pH}$-meter (HM-5S; TOA Electric Industrial Co. Ltd.,Tokyo, Japan).

Sensory evaluation: Sensory evaluation was carried out on sausage samples immediately. The sausage products were evaluated for color, flavor,taste and overall acceptability according to the procedures of American Meat Science Association(AMSA 1995).

Statistical analysis: A one-way ANOVA followed by Duncan's multiple range test (DMRT) were performed using IBM ® statistics software SPSS 11.00 (SPSS Inc., Chicago, IL, USA) to analyze and compare the data. Results were presented as mean $\pm \mathrm{SD}$ and $\mathrm{P}$ - values $\leq 0.05$ were regarded as statistical significance

\section{RESULT AND DICUSSION}

In this study, the improvement in quality and shelf life increase was determined, when oils herb usedagainst food borne in sausage product. For control sample, the moisture content decreased from 49.14 to $45.00 \%$, protein was decreased from 25.56 to $24.11 \%$, carbohydrates decreased from 3.91 to 
$3.11 \%$, ash and fats were increased from 3.14 to 6.19 and $18.25 \%$ to $21.59 \%$ after 3 months storage. The protein decrease may be due to protein hydrolysis by natural meat enzymes and bacterial enzymes that are produced as well as the loss of water soluble protein with separated drip(BadpaandSaghir 2014). The ash percent for all sausage samples increased gradually with increasing time of storage. Regarding ash results indicated that sausage had high substitute of herbs (sample control without oil mixture) contain high percentage of ash.These results are similar to that obtained by Gibrielet al. (2007) and Madkouret al. (2000).

Results in Table (2) indicated that the moisture, cure protein and carbohydrate were decreased by increasing storage period from zero to 90 days. At zero time the moisture, crude protein and carbohydrate were ranged from 49.11 to $49.59 \%, 25.21 \%$ to $25.52 \%$ and 5.10 to $5.32 \%$, and decreased after 90 days storage period at $-18^{\circ} \mathrm{C}$ which ranged from $45.83 \%$ to 46.03 , $24.15 \%$ to $24.39 \%$ and 4.51 to $4.81 \%$ in all treatments withoils mixture. Whereas, ash (4.79 to $4.72 \%)$, fat (20.72 to $20.33 \%)$ and $\mathrm{pH}$ values (6.33 to 6.66) were increased with increasing storage period for 90 days in all concentrations ofoils $(600,900$ and $1200 \mathrm{ppm} / \mathrm{kg})$. The highest moisture, crude protein and carbohydrate wereachieved at $1200 \mathrm{ppm} / \mathrm{kg}$ ofoil mixture of cardamom and coriander at zero time while gave the highest value at $\mathrm{pH}$ (6.95) after 90 days of storage period. Whereas the highest amount of ash and fat were recorded at $600 \mathrm{ppm}$ ofoil mixture after 90 days of storage. These results are in agreement with those reported by Nuzhatet al. (2002) Bahlol and Abd El-Aleem (2004) and Abd El-Aleem and Mohamed (2005). 
Sensory evaluation of prepared sausage using different concentration of oils mixture:

Colour and taste measurement are a critical objective quality parameter that can be used for quality index measurements of quality of the meat products as well as quality changes as a result of processing, storage and other factors (Busattaet al., 2008). Odor, overall acceptability and appearance are probably the most important attributes that influence the sensoryproperties for consumers. The consumer panel data of this treatments were tabulated in Table (3) and indicated that significant differences $(\mathrm{P}<0.05)$ 
Table (2): Chemical composition of sausage produsedwith cardamom and coriandermixture for 90 days storage period at $-18^{\circ} \mathrm{C}$.

\begin{tabular}{|c|c|c|c|c|c|c|c|}
\hline \multirow[b]{2}{*}{$\begin{array}{c}\text { Storage } \\
\text { time } \\
\text { Days }\end{array}$} & \multirow[b]{2}{*}{$\underset{\text { values }}{\mathrm{pH}}$} & \multicolumn{6}{|c|}{ Control } \\
\hline & & $\begin{array}{c}\text { Moisture } \\
\text { (96) }\end{array}$ & $\begin{array}{c}\text { Crude } \\
\text { protein } \\
(06)\end{array}$ & $\begin{array}{l}\text { Fat } \\
(0 \%)\end{array}$ & $\begin{array}{l}\text { Ash } \\
(96)\end{array}$ & $\begin{array}{l}\text { Carbo } \\
\text { hydra } \\
\text { te }(96)\end{array}$ & SEMI \\
\hline 0 & 6.2 & 49.14 & 25.56 & 18.25 & 3.14 & 3.91 & 0.16 \\
\hline 7 & 6.09 & 49.12 & 25.45 & 18.34 & 3.25 & 3.84 & 0.13 \\
\hline 14 & 6.14 & 47.52 & 25.23 & 19.12 & 4.33 & 3.80 & 0.05 \\
\hline 21 & 6.22 & 47.02 & 24.91 & 19.51 & 4.09 & 3.65 & 0.05 \\
\hline 28 & 6.35 & 46.38 & 24.63 & 20.25 & 4.21 & 3.61 & 0.08 \\
\hline 60 & 6.56 & 45.56 & 24.21 & 21.28 & 5.77 & 3.18 & 0.15 \\
\hline 90 & 6.76 & 45.00 & 24.11 & 21.59 & 6.19 & 3.11 & 0.02 \\
\hline \multicolumn{8}{|c|}{ Concentration of Coriander and Cardamom oil at ( $600 \mathrm{ppm}) \mathrm{Kg}$ (v/w) $9 \%$} \\
\hline 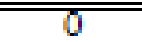 & 6.06 & 49.11 & 25.21 & 18.47 & 2.11 & 5.10 & 0.04 \\
\hline 7 & 6.11 & $49 . .00$ & 25.11 & 18.67 & 2.20 & 5.02 & 0.03 \\
\hline 14 & 6.13 & 48.61 & 25.00 & 19.04 & 2.43 & 4.92 & 0.11 \\
\hline 21 & 6.23 & 48.40 & 24.89 & 19.51 & 2.65 & 4.85 & 0.01 \\
\hline 28 & 6.25 & 48.10 & 24.75 & 19.55 & 3.51 & 4.79 & 0.04 \\
\hline 60 & 6.29 & 46.20 & 24.31 & 20.52 & 4.37 & 4.60 & 0.09 \\
\hline 90 & 6.33 & 45.83 & 24.15 & 20.72 & 4.79 & 4.51 & 0.05 \\
\hline \multicolumn{8}{|c|}{ Concentration of Coriander and Cardamom oil at $(900 \mathrm{ppm}) \mathrm{lg}$ (v/w) $6 \mathrm{rat}$} \\
\hline$\overline{0}$ & 6.08 & 49.52 & 25.50 & 18.44 & 1.30 & 5.24 & 0.05 \\
\hline 7 & 6.20 & 49.70 & 25.30 & 18.19 & 1.70 & 5.11 & 0.07 \\
\hline 14 & 6.23 & 49.01 & 25.01 & 18.44 & 2.53 & 5.01 & 0.06 \\
\hline 21 & 6.29 & 48.42 & 24.80 & 19.22 & 2.59 & 4.97 & 0.07 \\
\hline 28 & 6.33 & 48.22 & 24.73 & 19.35 & 2.80 & 4.90 & 0.05 \\
\hline 60 & 6.57 & 47.31 & 23.46 & 20.09 & 4.39 & 4.75 & 0.08 \\
\hline 90 & 6.66 & 46.00 & 24.32 & 20.33 & 4.72 & 4.63 & 0.06 \\
\hline \multicolumn{8}{|c|}{ Concentration of Coriander and Cardamom oil } \\
\hline 0 & 6.31 & 49.59 & 25.52 & 18.44 & 1.13 & 5.32 & 0.05 \\
\hline 7 & 6.42 & 49.45 & 25.11 & 18.70 & 1.53 & 5.21 & 0.08 \\
\hline 14 & 6.46 & 48.51 & 25.00 & 18.54 & 2.76 & 5.19 & 0.02 \\
\hline 21 & 6.60 & 48.03 & 25.00 & 19.01 & 2.89 & 5.07 & 0.04 \\
\hline 28 & 6.75 & 46.65 & 24.95 & 20.05 & 3.32 & 5.03 & 0.05 \\
\hline 60 & 6.82 & 46.33 & 23.75 & 20.11 & 4.85 & 4.96 & 0.03 \\
\hline 90 & 6.95 & 46.03 & 24.39 & 20.12 & 4.65 & 4.81 & 0.06 \\
\hline
\end{tabular}

Each value is the average of three Replicates. 
in all sensory characteristics were observed between sausage samples with different mixture oils concentrations and control sample.

The highest score of colour (8.47), taste (8.72), odor (9.43), appearances (8.21) and overall acceptability (8.02) were recorded by samples containing $1200 \mathrm{ppm}$ of oils mixture. Whereas the sausage samples with $600 \mathrm{ppm}$ of mixture oils gave the lowest scores of the colour, taste, appearance and overall acceptability being $7.32,5.23,7.78$ and 6.26 respectively. This result was agreements with Caceres et al., (2004)

Table (3): Sensory evaluation of prepared sausage contained different concentration of cardamom and corianderoils mixture ( $\mathrm{ppm})$.

\begin{tabular}{|c|c|c|c|c|}
\hline \multirow{2}{*}{ Storage time (Days) } & \multirow{2}{*}{ Control } & \multicolumn{4}{|c|}{ Concentration ppm of ois mixture } \\
\cline { 3 - 5 } & & $\mathbf{6 0 0}$ & $\mathbf{9 0 0}$ & $\mathbf{1 2 0 0}$ \\
\hline Colour & $8.01 \mathrm{a}$ & $7.32 \mathrm{~b}$ & $7.79 \mathrm{a}$ & $8.47 \mathrm{a}$ \\
\hline Taste & $7.36 \mathrm{a}$ & $5.23 \mathrm{c}$ & $6.50 \mathrm{a}$ & $8.72 \mathrm{a}$ \\
\hline Odor & $9.00 \mathrm{a}$ & $8.25 \mathrm{a}$ & $9.12 \mathrm{a}$ & $9.43 \mathrm{a}$ \\
\hline Overall acceptability & $7.12 \mathrm{~b}$ & $6.26 \mathrm{c}$ & $7.25 \mathrm{~b}$ & $8.02 \mathrm{a}$ \\
\hline Appearance & $8.02 \mathrm{a}$ & $7.78 \mathrm{a}$ & $8.00 \mathrm{a}$ & $8.21 \mathrm{a}$ \\
\hline
\end{tabular}

a-c: Means with different superscript within the same row differ significantly atp < 0.05 .

\section{The microbiological charactertics of sausage prepared using different}

concentration of oil mixture of oils: Cardamom and coriander oils mixture (1:4) ww concentration of 600,900 and $1200 \mathrm{ppm}$ were applied as natural preservatives during the processing of beef sausage. The effects of these preservatives on microbiological characteristic of prepared sausage were studied during 90 days storage period at $-18^{\circ} \mathrm{C}$ and compared with control. 
The microbiological characteristics were determined as the counts of total bacteria, yeast and molds.

Results of microbial microbiotaof prepared sausage contained different concentrations of cardamom and coriander oils mixture (1:4) ww during 90 days of storage at $-18^{\circ} \mathrm{C}$ were presented in Table (4). The results indicated that the total bacterial count of prepared sausage containing $1200 \mathrm{ppm}$ of oils mixture was lower than the treatments contained 600,900 ppm and control, which decreased from 3.30 to $1.88 \log$ cfu /g after 90 days, whereas the highest count of totalbacteria countwas recorded in the control samples after 90 days $(5.10 \log \mathrm{cfu} / \mathrm{g})$. In addition, Staphylococci, total coliform, yeast and molts not detected after 21 days of storage in samples count 1200ppm. Whereas, the control samples and samples contained $600 \mathrm{ppm}$ oilsmixtures gave the highest counts (total bacteriacount (5.10 and 4.62), Staphylococci(1.62 and 1.22),totalcoliform (1.64 and 1.44) andyeast and molts(1.62 and 1.38), respectively, after 90 days of storage. Similar finding were performed by Jay (2005).

\section{Antifungal activity of cardamom and coriander oils:}

Results in Table (5) showed the antifungal activity of cardamom and coriander oilsmixture against some fungal strains (Aspergillusfllavus, Aspergillusniger and saccharomyces cerevisiae).The inhibitory effect of these oils was detected using agar diffusion method.Results indicated that the antifungal activity of all tested oils mixture were varied from one to another and reached the maximum effect at $1200 \mathrm{ppm}$ concentration. The highest inhibition zone diameter was $11.50 \mathrm{~mm}$ and recorded by Saccharomyces cerevisiae at $1200 \mathrm{ppm}$. On contrary, the lowest inhibition zone diameter was 
attained by cardamom oil $(4.01 \mathrm{mmfollowed}$ by coriander oil $(4.25 \mathrm{~mm})$ at 600 ppm concentration against the growth of Aspergillusflavus. These results in agreement Yano et al (2006) reported that the inhibitory effects of cardamom and coriander oils significant increased with increasing the concentration of oil.

Antibacterial activity of cardamom and coriander oils: As seen in Table (6), cardamom and coriander oils markedly inhibition growth of most bacteria tested including Staphylococcus aureus, salmonella typhimurium, Bacillus subtilis and Escherichia coli. It could be noticed that the inhibitory effects differed with regard to the type of bacteria. Cardamom and coriander oils generally showed stronger antibacterial effects of for Staphylococcus aureus, Bacillus subtilis and E. coli than salmonella typhimurium in the presence of $1200 \mathrm{ppm}$ oils concentration, where the inhibition zones diameter of cardamom oil (1200 ppm) were 11.00, 15.30, 10.30 and $7.50 \mathrm{~mm}$, respectively and coriander oil (1200 ppm) produced inhibition zones 10.90, $12.40,11.10$, and $8.3 \mathrm{~mm}$ for the some tested bacteria strains, respectively. These results were in agreement withJoydeepet al (2014). 
Table (4): Microbial count $\left(\log _{10} \mathrm{cfu} / \mathrm{g}\right)$ of prepared sausage content different concentrations of cardamom and coriander oils mixture (1:4) w/w during 90 days storage period $\left(-18^{\circ} \mathrm{C}\right)$

\begin{tabular}{|c|c|c|c|c|c|}
\hline \multirow[b]{2}{*}{ Treatment } & \multirow[b]{2}{*}{$\begin{array}{c}\text { Storage } \\
\text { period } \\
\text { (days) }\end{array}$} & \multicolumn{4}{|c|}{ Microbial count $(\log \mathrm{cfu} / \mathrm{g})$} \\
\hline & & $\begin{array}{c}\text { Total } \\
\text { bacterial } \\
\text { count }\end{array}$ & $\begin{array}{c}\text { Staphylococ } \\
\text { ci count }\end{array}$ & $\begin{array}{c}\text { Total } \\
\text { Coliform }\end{array}$ & $\begin{array}{l}\text { Yeast and } \\
\text { mold }\end{array}$ \\
\hline \multirow{7}{*}{ Control } & 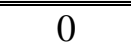 & $3.44 \mathrm{a}$ & $2.94 \mathrm{a}$ & $2.64 a$ & $2.25 \mathrm{a}$ \\
\hline & 7 & $3.92 \mathrm{a}$ & $1.40 \mathrm{a}$ & $1.88 \mathrm{a}$ & $1.92 \mathrm{a}$ \\
\hline & 14 & $4.08 \mathrm{a}$ & $1.40 \mathrm{a}$ & $1.88 \mathrm{a}$ & $1.88 \mathrm{a}$ \\
\hline & 21 & $4.22 \mathrm{a}$ & $1.42 \mathrm{a}$ & $1.80 \mathrm{a}$ & $1.84 \mathrm{a}$ \\
\hline & 28 & $4.40 \mathrm{a}$ & $1.48 \mathrm{a}$ & $1.78 \mathrm{a}$ & $1.78 \mathrm{a}$ \\
\hline & 60 & $4.62 c$ & $1.52 \mathrm{a}$ & $1.70 \mathrm{c}$ & $1.70 \mathrm{a}$ \\
\hline & 90 & $5.10 \mathrm{c}$ & $1.60 \mathrm{a}$ & $1.64 \mathrm{c}$ & $1.62 \mathrm{a}$ \\
\hline \multirow{7}{*}{600 ppm } & 0 & $3.42 \mathrm{a}$ & $2.92 \mathrm{c}$ & $2.44 a$ & $2.22 \mathrm{~b}$ \\
\hline & 7 & $3.82 \mathrm{a}$ & $1.40 \mathrm{c}$ & $1.82 \mathrm{~b}$ & $1.84 \mathrm{~b}$ \\
\hline & 14 & $4.06 \mathrm{a}$ & $1.36 \mathrm{c}$ & $1.74 \mathrm{c}$ & $1.74 b$ \\
\hline & 21 & $4.16 a$ & $1.30 \mathrm{c}$ & $1.66 \mathrm{c}$ & $1.66 \mathrm{~b}$ \\
\hline & 28 & $4.28 \mathrm{a}$ & $1.24 \mathrm{~b}$ & $1.52 \mathrm{c}$ & $1.50 \mathrm{c}$ \\
\hline & 60 & $4.40 \mathrm{a}$ & $1.20 \mathrm{c}$ & $1.48 \mathrm{a}$ & $1.44 \mathrm{c}$ \\
\hline & 90 & $4.62 b$ & $1.22 \mathrm{c}$ & $1.44 \mathrm{~b}$ & $1.38 \mathrm{c}$ \\
\hline \multirow{7}{*}{900 ppm } & 0 & $3.38 \mathrm{a}$ & $2.90 \mathrm{c}$ & $2.40 \mathrm{~b}$ & $2.20 \mathrm{~b}$ \\
\hline & 7 & $3.44 \mathrm{a}$ & $1.40 \mathrm{c}$ & $1.62 \mathrm{~b}$ & $1.62 \mathrm{~b}$ \\
\hline & 14 & $3.50 \mathrm{a}$ & $1.28 \mathrm{~d}$ & $1.40 \mathrm{c}$ & $1.48 \mathrm{~b}$ \\
\hline & 21 & $3.62 \mathrm{a}$ & $1.16 \mathrm{~d}$ & $1.28 \mathrm{c}$ & $1.30 \mathrm{~b}$ \\
\hline & 28 & $3.72 \mathrm{a}$ & $1.08 \mathrm{c}$ & $1.14 \mathrm{c}$ & $1.12 \mathrm{~b}$ \\
\hline & 60 & $3.80 \mathrm{a}$ & $\leq 1$ & $\leq 1$ & $\leq 1$ \\
\hline & 90 & $3.88 \mathrm{a}$ & $\leq 1$ & $\leq 1$ & $\leq 1$ \\
\hline \multirow{7}{*}{1200 ppm } & 0 & $3.30 \mathrm{a}$ & $2.84 \mathrm{c}$ & $2.32 b$ & $2.15 b$ \\
\hline & 7 & $3.22 \mathrm{a}$ & $1.20 \mathrm{e}$ & $1.44 \mathrm{~b}$ & $1.32 \mathrm{~b}$ \\
\hline & 14 & $3.04 \mathrm{a}$ & $1.08 \mathrm{e}$ & $1.12 \mathrm{c}$ & $\leq 1$ \\
\hline & 21 & $2.86 \mathrm{a}$ & $\leq 1$ & $\leq 1$ & $\leq 1$ \\
\hline & 28 & $2.48 \mathrm{a}$ & $\leq 1$ & $\leq 1$ & $\leq 1$ \\
\hline & 60 & $2.22 \mathrm{a}$ & $\leq 1$ & $\leq 1$ & $\leq 1$ \\
\hline & 90 & $1.88 \mathrm{a}$ & $\leq 1$ & $\leq 1$ & $\leq 1$ \\
\hline
\end{tabular}

The means with similar letters in the same column are not significantly different $(\mathrm{p}>$ $0.05)$ 
Table (5): Antifungal activities of cardamom and coriander oils:

\begin{tabular}{|c|c|c|c|c|c|c|c|}
\hline \multirow{2}{*}{ Organisms } & \multirow{2}{*}{ Blank } & \multicolumn{5}{|c|}{ Inhibition zone diameter (mm) } \\
\cline { 3 - 8 } & & \multicolumn{3}{|c|}{ Cardamom oil ppm } & \multicolumn{3}{c|}{ Coriander oil ppm } \\
\cline { 3 - 8 } & $\mathbf{6 0 0}$ & $\mathbf{9 0 0}$ & $\mathbf{1 2 0 0}$ & $\mathbf{6 0 0}$ & $\mathbf{9 0 0}$ & $\mathbf{1 2 0 0}$ \\
\hline Aspergillusflavus & - & $4.01 \mathrm{a}$ & $7.00 \mathrm{~b}$ & $925 \mathrm{~b}$ & $4.25 \mathrm{a}$ & $6.58 \mathrm{~b}$ & $8.44 \mathrm{~b}$ \\
\hline Aspergillusniger & - & $6.00 \mathrm{a}$ & $8.40 \mathrm{~b}$ & $10.00 \mathrm{c}$ & $6.12 \mathrm{a}$ & $8.30 \mathrm{~b}$ & $9.54 \mathrm{~b}$ \\
\hline $\begin{array}{c}\text { Saccharomyces } \\
\text { cerevisiae }\end{array}$ & - & $7.20 \mathrm{a}$ & $10.10 \mathrm{~b}$ & $11.50 \mathrm{c}$ & $7.35 \mathrm{a}$ & $9.35 \mathrm{~b}$ & $10.90 \mathrm{c}$ \\
\hline
\end{tabular}

The means with similar letters in the same column are not significantly $\operatorname{different}(\mathrm{p}>0.05)$

Table (6): Antibacterial activities of cardamom and coriander oils

\begin{tabular}{|l|c|l|l|l|l|l|l|}
\hline \multirow{2}{*}{ Bacterail strains } & \multirow{2}{*}{ Blank } & \multicolumn{5}{|c|}{ Inhibition zone diameter (mm) } \\
\cline { 3 - 8 } & & \multicolumn{2}{|c|}{ Cardamom oil ppm } & \multicolumn{3}{c|}{ Coriander oil ppm } \\
\cline { 3 - 8 } & - & $3.50 \mathrm{a}$ & $7.55 \mathrm{~b}$ & $11.00 \mathrm{~b}$ & $3.30 \mathrm{a}$ & $8.20 \mathrm{~b}$ & $10.90 \mathrm{~b}$ \\
\hline \hline $\begin{array}{l}\text { Staphylococcus. } \\
\text { aureus }\end{array}$ & - & $6.00 \mathrm{a}$ & $9.40 \mathrm{~b}$ & $15.30 \mathrm{~b}$ & $5.90 \mathrm{a}$ & $9.90 \mathrm{~b}$ & $12.40 \mathrm{~b}$ \\
\hline Bacillus subtilis & - & $3.70 \mathrm{a}$ & $5.10 \mathrm{~b}$ & $7.50 \mathrm{~b}$ & $3.55 \mathrm{a}$ & $5.70 \mathrm{~b}$ & $8.30 \mathrm{~b}$ \\
\hline $\begin{array}{l}\text { salmonella } \\
\text { typhimurium }\end{array}$ & - & $6.00 \mathrm{a}$ & $10.10 \mathrm{~b}$ & $10.30 \mathrm{~b}$ & $7.10 \mathrm{a}$ & $9.90 \mathrm{~b}$ & $11.10 \mathrm{~b}$ \\
\hline E.coli & & & & & &
\end{tabular}

The means with similar letters in the same column are not significantly different $(\mathrm{p}>0.05)$

\section{CONCLUSION}

From the obtained results, it could be concluded that addition of oils mixture to sausage at concentration of 600.900 and $1200 \mathrm{ppm}$ not only minimize lipid oxidation but also improved the sensory characteristics and enhanced the wholesomeness of the product during 90 day of storageat $-18^{\circ} \mathrm{C}$. Furthermore, during storage at $-18^{\circ} \mathrm{Csausage}$ prepared using $1200 \mathrm{ppm}$ oils mixture extended the shelf life for 90 day. Cardamom and coriander oils were 
found to have important antimicrobial activity against the test strains. In this regard the use of Cardamom and Corianderoils volatile compounds as natural preservatives in food products and it may be an alternative to the use of chemical additives.

\section{REFERENCES}

A. O. A. C (2000): Official Methods of Analysis of the Association of Official Agricultural Chemists, 17th ed, published by A. O. A. C.

Abd El-Aleem, I.M. and Mohamed, M.H.M. (2005): Preparing some meat products using soybean seed after removing the antinutritional matters. J. Annals of Agric Sci. Moshtohor, 43 (2): 627-647.

Akgul A (1993): Spice Science and Technology, Food TechnologyDernegei Publishing Publications, no. 15, Ankara, pp. 113-114

AMSA. (1995): American Meat Science Association. Research guidelines for cookery, sensory evaluation and instrumental tenderness of fresh meat. National Livestock and Meat Board. Chicago, IL.

Ayoughi, F., Barzegar, M., Sahari, M.A. and Naghdibadi, M. (2011): Chemical compositions of essential oils of Artemisia dracunculus L. and Matricaria chamomile and evaluation of their antioxidative effect. Journal of Agricultural Science and Technology 13: 79-88.

Badpa, A. and A. Saghir. (2014): Effect of whey protein concentrate on quality and shelf life of buffalo meat emulsion sausage. Scholars Journal of Agriculture and Veterinary Sciences. 1(4):201-210

Bahlol, H.El.M. andAbd El-Aleem, I.M. (2004): Beef sausage and beef burger production by adding treated mung bean. J. Annals of Agric. Sci. Moshtohor, 42 (4): 1791-1807.

Bakkali F, Averbeck S, Averbeck D, Idaomar M (2008): Biological effects of essential oils, a review. Food Chem. Toxicol., 46: 446-475

Baytop T (1984): Türkiye'deBitkilerileTedavi. İ.Ü. Yay. No: 3255, EczacılıkFak. No: 40, Istanbul. 
Bhuiyan MNI, Begum J, Sultana M (2009): Chemical composition of leaf and seed essential oil of CoriandrumsativumL. from Bangladesh. Bangladesh J.Pharmacol. 4: 150-153

Busatta C, Vidal R. S, Popiolski A. S, Mossi A. J, Dariva C, Rodrigues M.,R. A,Corazza F. C, Corazza M. L, Oliveira J. V \&Cansian, R.,L., (2008): Application of (Origanummajorana L.) essential oil as an antimicrobial agent in sausage. Food Microbiology. 25: 1, $207-$ 211. 24.

Caceres, E.,m Garcia, M.L., Toro, J. and Selgas, M.D. (2004): The effect of fructooligosaccharides on the sensory. Meat science volume 68 issue 2004 page $87-96$.

Coşkuner Y, Karababa E (2007): Physical properties of coriander seeds (Coriandrumsativum L.). J. Food Eng., 80: 408-416.

Desmond, E. (2006): Reducing salt: A challenge for the meat industry. Meat Science, 74(1), 188-196.

Ghani A (2003): Medicinal plants of Bangladesh: Chemical constituents and uses. 2nd ed. Asiatic Society of Bangladesh, Dhaka, p. 183.

Gibriel, A.Y.; Ebeid, H.I.K. and Abdel-Fattah, A.A. (2007): Application of Monascuspurpureus pigments produced using some food industry wastes in beef sausage manufacture. Egypt J. Food Sci., 35: 2745 .

Gould, G. W. (1996): Methods for preservation and extension of shelf life. International Journal of Food Microbiology, 33(1), 51-64.

Jay JM (2005): Indicators of food microbial quality and safety. Modern Food Microbiology, 7th ed, Eds., Jay, J.M., M.J. Loessner and D.A. Golden. Springer Science + Business Media, New York, pp: 473 $-496$.

JoydeepMazumder*, RachnaKumria, DevenderPathak (2014): Evaluation of Synergistic Antimicrobial Activity and Antioxidant Activity of blend of Essential Oil contains Fennel, Coriander, Ajowan and Caraway. Journal of Pharmacy and Biological Sciences. PP 87-94 
Karre, L., Lopez, K., and Getty, J. K.( 2013): Natural antioxidants in meat and poultry products. Meat Sci. 94:220-227

Kiessling, C. R., Cutting, J. H., Loftis, M., Kiessling, W. M., Datta, A. R., \&Sofos, J. N. (2002): Antimicrobial resistance of food-related Salmonella isolates, 1999-2000. Journal of Food Protection, 65(4), 603-608.

Korikontimath VS, Mulge R, Zachariah JT (1999): Variations in essential oil constituents in Highyielding selections of cardamom. J. Plantation Crops, 27:230-232

Lean L.P. and Mohamed S. (1999): Antioxidative and antimycotic effects of turmeric, lemon-grass, betel leaves, clove, black pepper leaves and Garciniaatriviridis on butter cakes. Journal of the Science of Food and Agriculture 79:1817-1822.

Madkour, M.H.; Ebeid, H.M.; Ashour, E.Z. and Gibriel, A.Y. (2000): Production and use of Monascuspurpureusas coloring agent in beef burger. Annals of Agric. Sci., Moshtohor, 38 (1): 317.

Mataysoh JC, Maiyo ZC, Ngure RM, Chepkorir R (2009): Chemicalcomposition and antimicrobial activity of the essential oil ofCoriandrumsativum. Food Chem., 113: 526-529.

Meng, J., and Doyle, M. P. (1998): Emerging and evolving microbial foodborne pathogens. Bulletin De L Institut Pasteur, 96(3), 151163.

Mildner-Szkudlarz, S., Zawirska-Wojtasiak, R., Obuchowski, W. and Gośliński, M. (2009): Evaluation of antioxidant activity of green tea extract and its effect on the biscuits lipid fraction oxidative stability. Journal of Food Science 74: 362-370.

Msaada K, Hosni K, Taarit MB, Chahed T, Kchouk ME, Marzouk B (2007): Changes on essential oil composition of coriander(CoriandrumsativumL.) fruits during three stages of maturity. FoodChem., 102(4): 1131-1134. 
Neffati, M., Sriti, J., Hamdaoui, G., Kchouk, M.E. and Marzouk, B. (2011): Salinity impact on fruit yield, essential oil composition and antioxidant activities of Coriandrumsativum fruit extracts. Food Chemistry 124: 221-225.

Nuzhat, H.; Imran, P.; Sultan, S.; Zobia, J. and Asif, I. (2002): Incorporation of legumes as non-meat protein extenders in fresh beef sausage. Pakistan J. Agric. Sci. 39 (3): 236-23

Politeo, O., Jukic, M. and Milos, M. (2007): Chemical composition and antioxidant capacity of free volatile aglycones from basil (Ocimumbasilicum L.) compared with its essential oil. Food Chemistry 101: 379-385.

Reddy, V., Urooj, A. and Kumar, A. (2005): Evaluation of antioxidant activity of some plant extracts and their application in biscuits. Food Chemistry 90: 317-321.

Ruberto G. and Baratta M.T., (2000): Antioxidant activity of selected essential oil components in two lipid model system. Food Chem., 69: 176-174.

Shahsavari, N., Barzegar, M., Sahari, M.A. and Naghdibadi, H. (2008): Antioxidant activity and chemical characterization of essential oil of Buniumpersicum. Plant Foods for Human Nutrition 63: 183188.

Smid, E. J., \&Gorris, L. G. M. (1999): Natural antimicrobials for food preservation. In M. S. Rahman (Ed.), Handbook of Food Preservation (pp. 285-308). New York: Marcel Dekker

Solomakos, N., Govaris, A., Koidis, P., and Botsoglou, N. (2008): The antimicrobial effect of thyme essential oil, nisin, and their combination against Listeria monocytogenes in minced beef during refrigerated storage. Food Microbiol.70 25:120-127.

Yano,Y, ;Satomi, M. and Oikawa, H, (2006): Antimicrobia effect of spices and herbs. Int. J. Food Microb. Ill, 6-11 .

Zink, D. L. (1997): The impact of consumer demands and trends on food processing. Emerging Infectious Diseases, 3(4), 467-469 


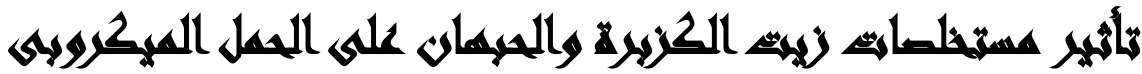

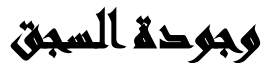

[؛]

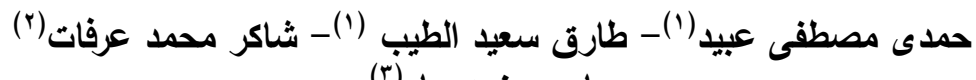

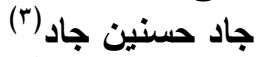

( ) كلية الزراعة، جامعة عين شمس r) معهز بحوث تكنولوجيا الاغذية، مركز البحوث الزراعية r) شركة كانو فليفر اند فراجرانسز

\section{المستخلص وتكرة}

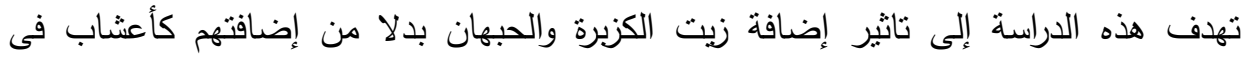

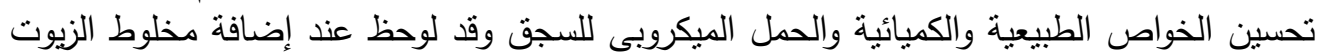

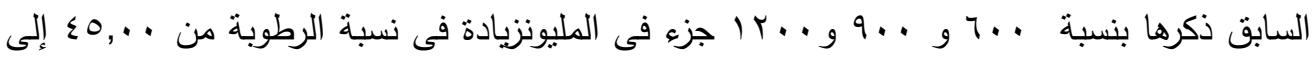

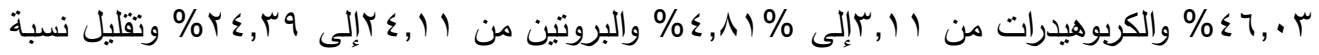

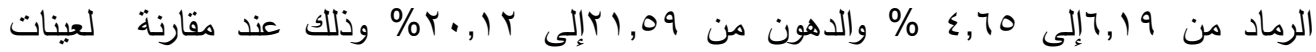
الكنترول وتركيز

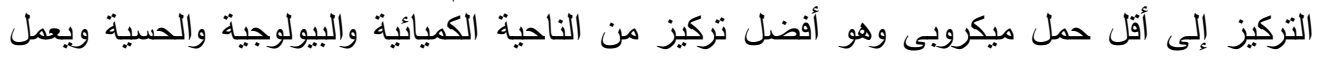
على زيادة الفترة التخزينية للسجق والحفاظ على ثبات الصفات المرغوبة لدئ لدى المستهلكين.

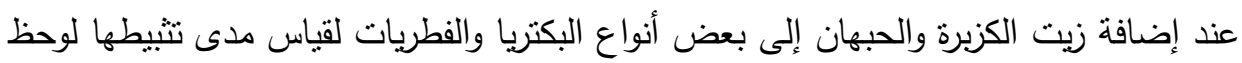
تثبط لهذة الميكروبات والفطريات الكزرة التهات 